Article (refereed) - postprint

Acreman, M.; Holden, J. 2013. How wetlands affect floods. Wetlands, 33

(5). 773-786. 10.1007/s13157-013-0473-2

(c) Society of Wetland Scientists 2013

This version available http://nora.nerc.ac.uk/502685/

NERC has developed NORA to enable users to access research outputs wholly or partially funded by NERC. Copyright and other rights for material on this site are retained by the rights owners. Users should read the terms and conditions of use of this material at http://nora.nerc.ac.uk/policies.html\#access

This document is the author's final manuscript version of the journal article, incorporating any revisions agreed during the peer review process. Some differences between this and the publisher's version remain. You are advised to consult the publisher's version if you wish to cite from this article.

The final publication is available at link.springer.com 


\title{
How wetlands affect floods
}

\author{
M. Acreman
}

Centre for Ecology and Hydrology, Crowmarsh Gifford, OX10 8BB, UK

man@ceh.ac.uk

\section{J. Holden}

School of Geography, University of Leeds, Leeds, LS2 9JT, UK

Corresponding author: Prof M Acreman, Centre for Ecology and Hydrology, Crowmarsh Gifford, OX10 8BB, UK. man@ceh.ac.uk

\begin{abstract}
It is widely recognised that wetlands play an important role in the hydrological cycle, influencing groundwater recharge, low flows, evaporation and floods. This has led to policies being formulated world-wide to conserve and manage wetlands to deliver these key services, especially flood risk reduction. Generic statements have often been published about wetland hydrological services but the term "wetlands" covers many land types, including wet woodlands, reedbeds, peat bogs, fens, and salt marshes. Each of these wetland types can have a hydrological function that is subtly different, making it difficult to generalise the flood reduction services of wetlands. In this paper we focus on two example wetland types (upland rain-fed wetlands and floodplain wetlands) to demonstrate why there are differences in flood functions both within and between wetland types. Upland wetlands generally tend to be flood generating areas while floodplain wetlands have a greater potential to reduce floods.
\end{abstract}


However, landscape location and configuration, soil characteristics, topography, soil moisture status and management all influence whether these wetlands provide flood reduction services.

Keywords: Wetlands, floods, water storage, runoff generation, water table, peat, hydrology

\section{Introduction}

The Millennium Ecosystem Assessment (2005) highlighted the key role of ecosystems in supporting human life, with a possible value of US\$ 33 trillion per year (Costanza et al. 1997). Wetlands contribute to social and cultural well-being (Fischer et al. 2009) and often have high economic value (Emerton and Boss 2004) because of the important ecosystem functions (Maltby et al 1996) and services they deliver (Maltby et al., 2013). More work has probably been undertaken on services that wetlands deliver than for any other ecosystem (Maltby and Acreman 2011). One of the most commonly quoted regulating services of wetlands is flood reduction; some wetlands are said to "act like a sponge" (an analogy which goes back as least as far as Turner, 1757, p30), storing water during wet periods and releasing it during dry periods (e.g. Bucher et al, 1993). As Maltby (1991) reports “...the case for wetland conservation is made in terms of ecosystem functioning, which result in a wide range of values including groundwater recharge and discharge, flood flow alteration, sediment stabilization, water quality." Wetland conservation has often been promoted as a potential means of flood management by organisations such as IUCN (Dugan, 1990), Wetlands International (Davis and Claridge 1993) and the Ramsar Convention on Wetlands of International Importance (Davis 1993). They have influenced international wetland policy (OECD 1996) and its uptake at the national (e.g. Zimbabwe - Mazvimavi 1994, and Uganda 
- Republic of Uganda 1995), and continental levels (e.g. Europe - CEC 1995; Blackwell and Maltby 2006; and Asia - Howe et al. 1992).

The term wetland covers many land types, including wet woodlands, reedbeds, peat bogs, fens, wet grasslands and salt marshes and each of these cover a range of sub-types. Each wetland type operates, hydrologically, in subtly (but sometimes very) different ways from other wetland types. A major review of scientific literature reporting hydrological functions of wetlands was undertaken by Bullock and Acreman (2003). Within their paper they reviewed the evidence for whether wetlands reduced flooding. While there are clear examples of the flood reduction services of many wetlands (e.g. Verry and Boelter 1975; Novitski 1978; Bedinger 1981; Hillman 1998), Bullock and Acreman (2003) reported only limited support for the generalised model of flood control by wetlands. They found that around $80 \%$ of relevant studies suggested floodplain wetlands reduced flooding, but they also found that $41 \%$ of studies on headwater wetlands indicated that those wetlands enhanced flooding. The inference from Bullock and Acreman (2003) is that the same wetland type might both attenuate and increase flood risk in different environmental settings or at different times of the year and that some wetland types provide flood attenuation services more commonly than others. However, their paper did not explain in detail the reasons for such findings. It is also the case that many wetland systems have undergone changes in hydrological function due to human intervention (e.g. drainage) (Bay 1969; Bedinger 1981; Price 1992; Holden et al. 2004; Holden et al. 2006). There is, therefore, a need to tease-out general processes that can be applied to understand the impacts of wetlands and wetland management on flooding. Improved understanding of flood processes associated with wetlands would enable scientists, practitioners and policy-makers to better predict how changes in wetland management might 
alter the role of a particular wetland in downstream flood risk. Improved predictions would enable expectations for wetlands and wetland management to be more realistic.

In this present paper we review the hydrological processes that generate floods and contrast them with those hydrological processes typically operating in wetland systems. The purpose of our paper is to report evidence for mechanisms that explain Bullock and Acreman's (2003) results. We refer to a range of wetlands, but focus on two wetland types in more detail (upland rain-fed wetlands and floodplain river-fed wetlands) to demonstrate differences in flood functions both within and between wetland types. The paper reviews five fundamental questions:

- What are the characteristics of floods that are influenced by wetlands?

- What are headwater flood generating processes that rain-fed wetlands influence?

- How does site management alter the influence of headwater rain-fed wetlands on floods?

- What are the downstream processes that river-fed wetlands influence?

- What are the downstream flood processes that site management of river-fed wetlands influence?

\section{Characteristics of floods}

Floods occur when a large depth of water flows over land that is normally dry. They may occur in response to a number of hydrological mechanisms, including high tidal levels (coastal flooding), direct precipitation (pluvial flooding), high groundwater levels (groundwater flooding) or high river flows (fluvial flooding) (Falconer et al. 2009). In terms of fluvial flooding, for perennially flowing rivers, this is inferred to mean that water has overtopped the confines of the river channel. Fluvial flooding may be caused by a number of 
factors such as clogging of a river channel by sediment (e.g. Martin-Vide et al. 2013), heavy rainfall, snow melt or a dam collapse. In this paper we are considering only river flow generated floods resulting from rainfall.

Large floods qualify as natural disasters and can be very destructive and lead to damage to property, agricultural land and infrastructure and in the worst case, loss of life. Smaller floods overtop riverbanks in limited areas and may not affect human infrastructure. Flood management has focused on reducing risks to people. However, floods are a vital part of many ecosystems (e.g. Benke 2001; Mosepele et al., 2009). For example, lateral connectivity between rivers and their floodplains during flood pulses is a key driving force for the river ecosystem (Junk et al. 1989; Tockner et al., 2001) bringing water and nutrient-rich sediment that produce fertile soils, habitats for birds, spawning grounds for fish and natural irrigation that provides lush pastures for livestock (Sparks 1995). Indeed, for many wetlands, flood inundation is necessary for their survival and hence upstream efforts to reduce flooding can threaten the existence of those wetlands (Zedler and Kercher, 2005).

Hydrologists do not simply define a flood in terms of land inundated, but as a significant increase in river discharge (Ward 1978; Haarhoff and Cassa 2009). Much flood analysis is undertaken using annual maximum flows, though the maximum flow in any year is not necessarily a flood in that water may not have overtopped the river channel. The flood hydrograph (Figure 1) defines the river discharge through time during a flood event and has a number of characteristics:

- the peak flow determines the maximum flood level and who or what gets inundated;

- the rise-time indicates how fast the flood water rises and so how quickly it reaches its peak and how much time there is to avoid it; 
- the lag-time between precipitation and the flood peak indicates how much warning could be given by measuring preceding precipitation and forecasting the coming flood;

- duration indicates how long the flood lasts;

- the flood volume tells us the total amount of water in the flood and helps define how much storage we might need to design into a flood management scheme.

There are thus many ways in which a flood could be altered by wetlands. For example, the peak or rate of rise could be reduced, the timing could be delayed or the volume decreased.

River flow is the net product of a range of water flow processes across and through the landscape. Some flow pathways for water across and through the landscape attenuate its delivery downstream (e.g. water movement through small pore spaces in a fine textured soil, or rough geometry and debris obstructed river channels; Lin 2010; Thomas and Nisbet 2012) while other pathways enable rapid transfers of water downstream and may increase the size of the flood and reduce its lag time (e.g. overland flow generation or uniform, unobstructed river channels; Burt 1996; Brookes 1985). These processes can be divided into two main groups: (1) the movement of water from precipitation through or over the land surface to the river; and (2) the movement of water along the river channel. We use this classification to describe processes in sections 5 and 7 respectively.

\section{Characteristics of wetlands}

The influence of a wetland on floods depends on the type of wetland (Bullock and Acreman, 2003) and its hydrological state (Delaney 1995). Ecological classifications of wetlands are often based on vegetation communities (such as Rodwell 1991). However, to understand the implications for floods, we need to consider a wetland classification based on hydrological, 
morphological or landscape settings, such as the classification developed by Novitsky (1978), Cowardine et al. (1979), Brinson (1993) and Lloyd et al. (1993). In the broadest terms freshwater wetlands can be classified hydrologically according to their landscape location and water supply mechanism (i.e. precipitation-fed, river-fed and groundwater-fed) as shown in Figure 2 (Acreman and Miller 2007). Many wetlands have two or all three of these water supply mechanisms. Landscape location defines broadly whether wetlands are upstream in areas of flood generation or downstream in lowland areas adjacent to rivers in flood. There is a strong association between the two aspects of classification as headwater wetlands may be dominated by rainfall supply, whereas downstream wetlands may be dominated by river flow supply. Some wetlands are separated from the river system and may be primarily fed by groundwater. Fens on sloping groundwater seeps or in lowland topographic hollows are good examples. Although these fens, which are separated from river channels (and therefore do not receive river flood waters), have the capacity to store water locally and to generate local runoff when saturated, they tend to respond to longer wet and dry periods rather than short term rainfall. There is a dearth of data on what influence such fens may have on river floods at larger scales. This paper focuses on two broad water mechanism or landscape wetland types where there is a larger amount of process-based hydrological evidence within the literature; headwaters where precipitation is transformed to runoff and downstream wetlands where wetlands adjoin rivers (on floodplains).

\section{Upstream flood processes that wetlands could influence}

Rain falling on the land can do one of four things:

- evaporate (or be lost to the atmosphere via transpiration from vegetation) 
- collect on the surface in hollows;

- run over the surface to a water course (overland flow); or

- infiltrate into the soil and move through it (subsurface flow).

The topography of the landscape may enable flowing water from other locations or from precipitation to collect in hollows. These hollows may range from $\mathrm{mm}$-scale depressions in the soil surface to tens of km-scale basins. The larger-scale depression features may result in wetland development and may offer substantial water storage. Their impact on river flooding depends on whether such systems are connected to a river network or whether they are more, closed endorheic systems with no downstream landscape and are thus neutral to floods.

The latter two processes in the list above define flow pathways (surface and subsurface) (Figure 3), which are important because they control the speed of water movement, as well as having an influence on its quality, such as $\mathrm{pH}$, solute and sediment content. The relative importance of the flow pathways in any river basin varies with climate, topography, soil character, vegetation cover and land use, and may vary through time at one location (e.g. seasonally) with antecedent moisture and with precipitation intensity and duration (Burt 2001). The runoff processes are not independent of one another and water travelling over the surface at one point may later take the form of subsurface flow and vice versa (McDonnell 2003).

Overland flow can result from either of two hydrological processes. Infiltration-excess overland flow occurs when rainfall intensity is so great that it cannot infiltrate into the soil; in this situation overland flow consists of water that has not been within the soil. This type of surface runoff is most likely on soils with low infiltration capacity and may be considered to most frequently come from those parts of the catchment where the soils have this 
characteristic (the 'partial contributing area' concept - Betson 1964). The other type of surface runoff is saturation-excess overland flow, which can occur at much lower rainfall intensities and is produced when the soil is saturated (except perhaps for some trapped gas bubbles within the soil); the water at the surface is a mixture of water that has been within the soil mass that is returning to the surface from upslope (return flow) and fresh rainwater that cannot infiltrate (Burt and Butcher 1985). Saturation-excess overland flow occurs when the soil storage is full of water due to infiltration or lateral soil water movement (Burt 1996). Water loss may be a slow process through seepage or evaporation, so overland flow can occur for long periods after rainfall has ceased, particularly along hill toes where the soil continues to be supplied by water draining from upslope (Burt 1996). The source areas (parts of the hillslope which contribute runoff) for saturation-excess overland flow will vary over time (the 'variable source area concept' - Hewlett and Hibbert 1967), expanding during rainfall events or cool, wet seasons, and may be very different from those for infiltrationexcess overland flow. During wet winter months, even those wetlands that normally reduce peak flows may actually contribute to a higher flood peak because they are fully saturated (Burt 1995). Devito et al. (1996) found that during seasons with large water inputs, swamps in the Canadian Shield overland flow dominated in the peatland. In extreme circumstances, the whole basin may be saturated and flood magnitude is controlled primarily by rainfall. Catchments dominated by overland flow processes are likely to have high flood peaks, since water travel times to the river channel are likely to be much shorter than if water was slowed by movement through the soil or rock. These processes form the basis of most hydrological rainfall-runoff models (e.g. Beven and Kirkby 1979; Moore 1985).

Once water has infiltrated into the soil, subsurface movement (throughflow) may occur between the grains of the soil matrix, through small micropore spaces. It may also occur 
within the soil by flow through networks of cracks and root channels known as macropores (Beven and Germann, 1982), or larger cavities known as soil pipes (Jones 2010). Flow velocities through macropore networks tend to be greater than through micropore spaces within the soil. Bromley et al. (2004) found that the rate at which water moved through peat (termed hydraulic conductivity) at Thorne Moor, UK, varied by several orders of magnitude depending on the presence of different macropore pathways. So if a soil has plentiful macropore networks, then it may be prone to enhanced river flow peaks even if it is dominated by subsurface flow (Jones 1997; 2010).

The main conclusion for wetland flood attenuation of the conceptualisation of runoff processes described above is that there are two potential areas of water storage; in hollows on the surface and within the soil. Undulating topography is required to produce hollows, and unsaturated soil is required to provide room for soil water storage, so that the wetland can store precipitation before saturation-excess overland flow is generated. Macropore and pipe networks may reduce the ability of a wetland to store water if these pathways allow water to readily escape. Furthermore, natural systems are rarely simple. For example, sometimes after very dry weather, or a wildfire, even if there is storage capacity within the wetland, peat in many wetlands can become hydrophobic (Eggelsmann et al. 1993) or have a reduced infiltration capacity (Holden et al. 2013) and potentially generate infiltration-excess overland flow even when not saturated. Thus fast flood-generating overland flow might develop even when there is plentiful storage capacity within the wetland. Nevertheless, this effect seems to be restricted and typical surface infiltration rates in wetlands are high when the water table is not at the surface (e.g. Holden and Burt 2002a). 


\section{How upland rain-fed wetlands relate to flood generation processes}

In certain topographic locations water is stored in surface depressions, which reduces peak flows. Ludden et al. (1983) reported that depressional wetlands in the Devils Lake basin of North Dakota could store $72 \%$ and $41 \%$ of total runoff volume from a 2 -year and 100 -year frequency rainfall event, respectively. However, the storage capacity of such wetlands and their influence on downstream flooding depends on the size and location of the wetland relative to the drainage network (Heathwaite, 1995) and the time of year (Ogawa and Male 1986). Quinton and Roulet (1998) and Glenn and Woo (1997) reported that some Canadian peatlands operate as a single source area with rapid runoff response creating floods when the water table exceeded the depression storage capacity of the peatland pools. Relatively slower responses and smaller floods occurred when pools became disconnected into separate microcatchments during drier periods.

The spare capacity for soil water storage of headwater wetlands to collect fresh rainfall can vary between sites, with wetland type and between years. Soil moisture deficits during dry years in boreal forested peatlands can have a significant impact on the magnitude of the subsequent spring flood peaks (e.g. Woo and Young 1998; Hillman 1998). However, the ability of many upland wetlands to store incoming fresh rainwater has been found to be limited. McCartney (2000) studied small headwater wetlands (dambos) in Zimbabwe that are protected because they are assumed to reduce floods and augment low flows. He found that saturation-excess overland flow, arising within the wetlands, was the principal mechanism of storm discharge generation in catchments in Zimbabwe. The dambos he studied had a small capacity to absorb rainfall at the start of the wetland season, when water table levels are low, but soon became saturated and contributed to flood runoff thereafter. 
While there are a multitude of wetland types that can occur in upland areas those that tend to cover large areas of uplands (rather than isolated pockets) can often be in the form of bogs. Bogs are ombrotrophic receiving virtually all of their water from precipitation and can be subdivided into blanket bogs and raised bogs. Blanket bogs often consist of a mosaic of different peatland types, but the dominant type of peatland within them is a blanket of ombrotrophic peat, typically between 0.5 and $3 \mathrm{~m}$ thick that covers the landscape (Bragg and Tallis 2001). Raised-bogs form a dome of peat under which there is an in-filled water body or fen peat and mineral sediments. Domes may be 2 to $5 \mathrm{~m}$ higher in their centres than their margins, with peat thicknesses as great as $8 \mathrm{~m}$ (Forster and Glaser 1986).

To reduce floods, in headwater catchments, where river flow is generated, the water level in the wetland needs to be sufficiently low to have enough capacity and responsiveness to store water rapidly. For many bog systems low water tables are not common as it is frequent saturation which keeps them maintained as bog ecosystems. Some wetlands are close to saturation for most of the year, such as blanket bogs in Newfoundland and these rarely act to attenuate flow and are much more likely to contribute to storm runoff due to their propensity for rapid saturation (Price 1992). Graphs of water level in wetlands through time help define water storage processes (Mitsch and Gosselink 2007; Holden et al 2011). As the water level rises, the wetland is drawing water into storage and as the level falls it is releasing water. Figure 4a shows seasonal water level fluctuations of 0.1-0.2 $\mathrm{m}$ in an upland plateau bog. In Figure $4 b$, however, a typical blanket peat response is shown whereby water tables remain close to the surface and respond very quickly to most rainfall events, with a fast rise to the surface leading to saturation-excess overland flow, or near-surface throughflow. The difference in response of the two wetlands is critical for influencing the coincidence of rainfall and water storage availability. 
Holden and Burt (2003a) studied blanket bogs on the English Pennines and found that the water table was within $40 \mathrm{~cm}$ of the surface for $80 \%$ of the year and concluded that when it rained there was little space for water storage, so most of the rainfall flows over the peat surface (saturation-excess overland flow) and quickly into the river. Water table drawdown in blanket peat tends to occur as a result of gravitational drainage across the slope over only the upper few $\mathrm{cm}$ of the peat profile. Below this depth (typically $\sim 10 \mathrm{~cm}$ ) then only evaporation further draws down the water table because the hydraulic conductivity of deeper blanket peat is so tiny (Holden and Burt 2003c). Even at $50 \mathrm{~cm}$ depth the water table in blanket peatlands can rise to the surface within a few minutes once rainfall begins as in situ unsaturated peat is still largely water (Price, 1992). In blanket peatlands there is also flow through natural pipes (Holden et al 2002), which may transport between 10-14 \% of the river discharge (Holden and Burt 2002b; Smart et al. 2013), but the pipes respond quickly to rainfall despite often being $>50 \mathrm{~cm}$ below the peat surface. Of course there may be large continental bogs where there is little overall gradient (other than microtopography) where water tables are at, or close to, the surface or where there is surface ponding, but where overland flow is very slow because topographic gradients are low.

The Flood Studies Report (NERC 1975) and its follow-up, the Flood Estimation Handbook (CEH, 1999) and associated publications (e.g. Kjeldson 2009, Kjeldsen and Jones 2009), contain the results of world-leading flood studies. One of the key elements to these reports was the classification of soils according to their winter rain acceptance potential (WRAP) which indicates how much rain the soil can store before flood runoff is generated. Welldrained soils are in WRAP class 1 and poorly drained soils are in WRAP class 5. When the size of historical flood peaks was assessed for 501 different UK rivers, it was found that the 
WRAP class of the soils in the catchment had the greatest influence. The more soils in the river basin with high WRAP class, the greater the flood peaks. Maps of WRAP class show that many wetlands, such as upland blanket peats, are in class 5 because they are normally saturated and have little available room for water storage.

\section{Site management implications for the influence of upland rain-fed wetlands on floods}

Much of the above discussion has focused on the influence of wetlands on floods compared with absence of wetlands. However, many wetlands are not entirely natural and are managed for specific purposes, such as intensive agricultural use following drainage. For example, the USA has lost some $54 \%$ of its original 87 million hectares of wetlands (Tiner 1984), primarily to drainage for agricultural production. Drainage has also been a major cause of wetland alteration or loss in Asia, Latin America and the Caribbean (WCMC 1992).

Wetland drainage has resulted in changes in water flow paths through and over wetlands (e.g. Holden et al. 2006). On sloping wetlands, such as upland blanket peatlands, the creation of drainage channels interferes with the natural pattern of water flow across hillslopes and this change in flow path can cause less water to reach parts of the slope from above and therefore lead to lowering of the water table across much of the slope (Holden et al. 2004). Field data demonstrates drained peatlands tend to have more subsurface flow and relatively less overland flow as a result (Holden and Burt 2003b), but this is spatially dependent on topography, drain locations and peat type. Drainage has been reported to both increase and decrease flood peaks from wetlands (Holden et al. 2004). For example, Burke $(1968 ; 1975)$ recorded much higher peak flows from un-drained peat areas than from drained areas, Kloet 
(1971) found that peak flows were increased by drainage, whilst Moklyak et al. (1975) concluded that drainage does not always affect the maximum discharge, but may either decrease or increase it in some circumstances.

Most drainage studies have simply measured inputs and outputs of water, which often means we cannot explain why there are differences in responses between different catchments even when the same type of wetland is present. Two main changes to hydrological process are likely to result from artificial drainage. The first is that there is an increased water storage capacity within the wetland reducing peak flows and increasing lag times. The second is that drainage channels (whether open cut or subsurface) now provide channels for rapid and direct flow to the stream. This may increase peak flows in the stream. The net result on flood peaks may depend on the density and orientation of drainage (Holden et al. 2004; Lane and Milledge 2013), slope and local vegetation (e.g. Gilman 2002; Holden et al. 2008) and the type of wetland or peat present (McDonald 1973). However, even where the dominant result is to increase water storage capacity within the wetland which supports the attenuation of flood flows, the overall result may still be an increase in flood peaks at the catchment scale. This may not seem intuitive but it relates to channel networks and flood wave synchronosity (Holden 2005a). Effects depend on event and location within the watershed, depending on synchrony between tributary and main channel peaks. A management change in one part of a wetland can have a very different impact on river flow and flooding to a similar change in another part of the wetland depending on its location (Holden 2005a). Thus it is necessary to include river channel network flow modelling and measurement as well as wetland flow modelling and measurement in any research that seeks to determine the influence of wetland management on flood flows. The same synchronosity effect has been demonstrated for 
reservoir-based flood management (Ramsbottom 1994) and drainage for afforestation (Acreman 1985).

Drainage of upland blanket peatlands has been shown to cause enhanced development of soil pipes (Holden 2005b). As the amount of pipe flow in a river basin increases, travel times to the river channel are likely to be altered. The net effect will depend on whether pipes are a faster or slower route for water than the other dominant pathways in blanket peatlands and further work is required to fully understand such effects. It is not known how much more water is delivered by pipes in drained or degraded blanket peatlands, but the long-term increase in piping over time in drained peat basins has been shown to have an influence on river flow at least at the small basin scale (Holden et al. 2006).

In many places wetland managers are investing in blocking drains to restore the hydrological conditions suitable for wetland flora and fauna and carbon capture (Armstrong et al. 2010; Howie et al. 2009; Wallage et al. 2006; Wilson et al. 2011b). The influence of drain blocking on flood flows has been notoriously difficult to detect at the basin scale. However, for blanket peat, modelling work has suggested that drain-blocking could reduce flood flows downstream (Ballard et al. 2011) and recent field data collected by Wilson et al. (2011a) for a blanket peatland at Vrynwy in Wales indicates that the increases in water storage after restoration produced lower discharge rates observable at the level of both drains and hill streams; as well as greater water table stability, reduction in peak flows and increases in water residency after rainfall. Numerous studies of peatland rewetting (e.g. Holden et al. 2011; Waddington et al. 2011; Wilson et al. 2011a) have suggested that many hydrological processes do not fully recover within the initial few years after restoration due to earlier changes in the peat structure and consolidation resulting from degradation. Thus the timescale for detecting flood 
responses to management interventions in such systems may be longer than most monitoring projects to date (Holden et al. 2011).

Field observations have shown that vegetation cover can affect the velocity of water flowing across wetlands and hence flood generation (Holden et al. 2007). In blanket peat, Holden et al. (2008) showed using plot scale measurements that Sphagnum slows the flow of water across peat surfaces compared to sedge-covered surfaces and bare peat surfaces (an order of magnitude slower). Importantly, the empirical data collected by Holden et al. (2008) for different slopes, water depths and vegetation covers enables prediction of overland flow velocity if the topography, vegetation cover and rainfall is known. Recent modelling studies have also suggested that the surface vegetation cover is likely to be of great importance (more so than the presence or absence of ditches for example) in the timing of the flood peaks from upland wetlands (Ballard et al. 2011; Lane and Milledge 2013). Grayson et al. (2010) showed for the first time using catchment-scale field data (at a $11 \mathrm{~km}^{2}$ scale) evidence from a longterm blanket peat hydrograph record that during times when the proportion of the basin with bare peat was greater (e.g. $9 \%$ bare) there were higher peaks per unit rainfall and narrower hydrograph shapes than periods when vegetation cover was more widespread.

\section{Downstream flood processes that wetlands could influence}

Floodplain wetlands have been used to manage floods on the large rivers of the world including the Mississippi (Bedinger 1981) and Rhine (Baptist et al. 2004). Doyle (1987) calculated that maximum floods in the Charles River are extremely low compared to the adjacent Blackstone River because the latter has smaller floodplain wetlands. The flood attenuation effect of floodplain wetlands has been widely appreciated by engineers as a 
means of flood management. The US Corps of Engineers (1972) calculated that the flood reduction function of 3,800 hectares of floodplain storage on the Charles River, Massachusetts saved US\$17 million worth of downstream flood damage each year.

In headwater catchments, the dominant processes controlling flood characteristics are those related to the transfer of precipitation to flow over or through the soil. To reach downstream flood risk areas in the lowlands, most water will have passed along the river channel, which has significant implications for the flood hydrograph characteristics. Generally, the friction with the river channel reduces flood peak discharge and rise time - a process called flood attenuation (Archer 1989) - but the peak and rise time may be increased by flood flows joining from tributaries and interactions with the floodplain (Bates et al. 2000). The further downstream, the more difficult it is to quantify the impact of headwater management activities on flood risk due to effects being overwhelmed by processes operating elsewhere in the catchment. Thus it is not easy to demonstrate potential implications of, for example, any impacts of deforestation and drainage in the Himalayas on increased floods in Bangladesh (Agarwal and Chak 1991). This may be the reason that Forest and Walker (1970) and Darmer (1970) concluded that basin storage is statistically insignificant in explaining the variability of flood peaks downstream.

The rate of attenuation of a flood wave along a river is related to several characteristics of the river channel including the wetted area (size of the channel), the bed roughness and sinuosity of the river (Rameshwaran 1999). In narrow, deep river channels, the wetted area is small (for the same flow) compared to a wide shallow channel, i.e. the river has a larger area of contact with the bed. This contact slows the velocity of the water and reduces the flood peak discharge. The degree of reduction is also dependent on the roughness of the bed and 
floodplain. Silt, sand and concrete are considered smooth, whereas cobbles, boulders and trees are considered rough and the Manning ' $n$ ' coefficient is widely used as an index of roughness (Chow 1959). Fine river sediments, often found in river pools, have a typical Manning roughness value of 0.02 , whereas riffles composed of gravel, the value may be 0.03 (Cowan 1956). In-channel vegetation, such as bushes (Righetti \& Armanini, 2002) bushes and trees in channels have higher resistance than smaller plants such as grasses, much depending on the morphology and flexibility of plant stems (Nepf, 1999). When river flow exceeds the capacity of the normal channel, water spills over onto the floodplain (Figure 5a), which can increase the wetted area enormously; the river may be $50 \mathrm{~m}$ wide, whereas the floodplain may be $500 \mathrm{~m}$ wide. As with the river channel, floodplain cover is important in determining its roughness, especially where dense vegetation is present (Sun et al. 2010). A change of vegetation from wet meadows to the shrubs and trees can double the size and depth of the inundated area for the same size of the flood (Swiatek et al. 2008). Vegetation types has an important influence over flow resistance and hence the degree of flood attenuation. Harvey et al. (2009) found that flow velocities were $29 \%$ greater in sloughs compared to more densely vegetated ridges in the Everglade wetlands, USA. Wooded wetlands in particular increase flood storage, reduced flood peaks and increase peak travel time (Thomas $\&$ Nisbet, 2007). Manning roughness values of 0.055 were used to model floodplain woodlands (Bates et al. 1992).

In Manning's equation velocity is directly proportional to the roughness. Slope is important but less so than hydraulic radius as its exponent is smaller. A sinuous channel has a longer flow path length than a straight channel so the length in contact with bed, banks and floodplain is greater and attenuation is greater. Many studies have documented the attenuation of flood peaks along river channels, such as on the River Wye in the UK Flood 
Studies Report (Natural Environment Research Council 1975). Similar results for floodplains were found in West Africa (John et al. 1993).

The topography of the floodplain and its connection with the river is a further important factor. On floodplains with large depressions or where the floodplain is only connected at specific points (Figure 5a), such as where there is no levee, water may not flow along the floodplain parallel with the river flow (Figure 5b), but may be stored. In such cases, the size of the storage dominates attenuation, rather than floodplain roughness. Hooijer (1996) calculated that flooding of 3500 ha of floodplain in the Shannon valley, Ireland, to an average depth of $1 \mathrm{~m}$ represented a storage equivalent to one day of peak discharge (around $400 \mathrm{~m}^{3} \mathrm{~s}^{-}$ $\left.{ }^{1}\right)$.

In hot climates a significant amount of the water on the floodplain may evaporate, further reducing flood magnitude downstream, as in the inner Niger delta (Zwarts et al. 2005), Okavango and Sudd (Sutcliffe and Parks 1989). Flood water may also be lost during floodplain inundation by infiltration if the soils are sandy, which was found to be the case in India (Nielsen et al. 1991). In most floodplains soil water storage tends to be play a minor role compared to surface topography, however storage in floodplain ditches and channels may be have some small influence (Acreman et al. 2011).

8. Site management implications for the influence of downstream river-fed wetlands on floods 
A logical extension of the evidence that floodplain wetlands can attenuate floods is that management of these wetlands may enhance or reduce this effect. Engineers have manipulated floodplain wetlands for many years to protect downstream assets (Morris et al. 2005). To protect Lincoln, UK, engineers selected management of the floodplain wetland upstream (termed controlled washlands) as an economic alternative to conventional channel improvements through the city (Wakelin et al. 1987). This involves embankments and sluice gates to let in and retain flood water when required, but excluding water from entering the washlands when not required, as the washland system offers maximum storage when empty.

In many parts of the world, floodplain wetlands have been separated from the river by constructing embankments to protect riparian land for agriculture or urban development. Whilst this may protect the area behind the embankment, it may increase flood risk downstream due to loss of storage and attenuation. Modelling of the River Cherwell, UK (Acreman et al. 2003), showed that construction of embankments would remove flood water storage and increase the peak flow downstream near the city of Oxford by $57 \%$ (Figure 6).

While there can be significant above ground water storage on floodplains, water storage is also available in the soils and any floodplain channels. As with headwater wetlands, soil storage depends on the saturation conditions before the flood event. Management of ditch and soil water levels thus influences flood water and flood attenuation. The Somerset Levels and Moors in the UK is an extensive floodplain fen wetland drained by a network of ditches, whose water level is controlled by pumping stations and sluice gates (Acreman et al. 2007). Water levels are kept low in the winter where agriculture is the main priority, whilst levels are high in wildlife conservation areas. Acreman et al. (2011) assessed the trade-off in flood storage loss against ecological gain at different water table levels for the Somerset Levels and 
Moors. They calculated that raising water levels in ditches in one of the catchments to meet ecological targets in winter would result in the loss of flood water storage volume equivalent to $3 \%$ of the medium annual flood volume.

\section{Summary and conclusions}

As Bullock and Acreman (2003) concluded, many papers report wetlands reducing floods, some conclude no impact, while others find evidence of wetlands increasing floods. This variation results partly from the wide range of ecosystems referred to as wetlands and one would not expect them to act hydrologically in the same manner. Even the same type of wetland can act as a source or sink for flooding depending on the precise characteristics of the individual wetlands, its landscape location, on hydrological conditions or on how it is managed. Many other basin characteristics influence the magnitude of floods on a river, including rainfall, drainage area, soil type, vegetation cover and slope and this influence may be greater than exerted by the existence or absence of wetlands. Indeed it should be noted that wetlands tend to cover a small percentage of most river basins and that during major catastrophic floods, the whole basin may be saturated, and flood magnitude is controlled primarily by rainfall, such that the presence or absence of wetlands, or their management, has no effect. This is analogous to the debate concerning the influence of forests on floods that although forests can play a certain role in delaying and reducing peak floodwater flows at local levels, scientific evidence clearly indicates that forests cannot stop catastrophic largescale floods (CIFOR 2005).

This paper posed a set of questions, the answers to which are summarised below: 
What are characteristics of floods that are influenced by wetlands?

Wetlands can influence the peak flows, timing, volume and duration of floods. However, the direction of influence can be both positive and negative.

What are headwater flood generating processes that rain-fed wetlands influence?

Rain-fed wetlands and their managed condition influence pathways of how precipitation reaches the river, by controlling overland flow, throughflow and groundwater flow. When wetland soils have surface hollows and are dry they have more potential to store newly arrived rainwater. When wetland and surface hollows are full they generate flood runoff.

How does site management alter the influence of headwater rain-fed wetlands on floods? Drainage speeds-up flow but also lowers water tables down-slope increasing storage. Thus net effects are difficult to measure. Impacts depend on topography, layout of drainage or other management intervention and location in the headwater catchment with respect to the drainage network. Re-vegetating wetlands reduces the speed of overland flow and potentially reduces the flood peak during some events.

What are the downstream processes that river-fed wetlands influence?

Floodplain wetlands slow flood wave speed and store large quantities of water, primarily on the surface, that flow back into the river later, evaporate or recharge groundwater. Floodplains with rough vegetation (e.g. trees and shrubs) have high friction and slow flood wave speed.

What are the downstream flood processes that site management of river-fed wetlands influence? 
Separating a floodplain wetland from its river by embankments removes flood storage. Raising water levels in a floodplain reduces the potential for additional soil water storage when floods occur. Both increase floods. Judicious management of floodplain storage enhances flood reduction, such as planting of shrubs and trees to increase roughness and building structures that allow water onto the floodplain, but slow its flow back to the river.

Figure 7 summaries the above conclusions by showing the relative magnitude of floods in river basins with different wetlands under different management regimes. River basins display natural variation in flood magnitude resulting from their characteristics, such as soil type, when no wetlands are present. For example, catchments with impermeable soils have larger floods than those with permeable soils. In catchments with generally permeable soils, the existence of the wetland may have more influence over floods than in catchments with impermeable soils.

Our specific conclusions are that five characteristics of wetlands largely determine their influence on floods.

1. Landscape location and configuration. In a broad sense, upland wetlands tend to be flood generating areas. Rainfall normally increases with altitude and upland wetlands are frequently saturated and have little water storage potential. Downstream wetlands, particularly floodplains, have a greater potential to reduce floods. Some wetlands are in endorheic hollows in the landscape. Whilst they may capture and hold local rainfall and runoff, they are not in direct connection with rivers and so have little influence on river floods.

2. Topography. The morphology of the wetland controls its ability to hold water on the surface and reduce floods. Depressions and ridges support water retention. 
3. Soil characteristics. Grain size, organic matter content, and hydraulic conductivity control the ability of soils to absorb water and the speed of movement of water through the soil. Coarse-grained soils allow water to move more quickly. The existence of macroporous preferential pathways allows water to move more rapidly through the soil.

4. Soil moisture status. Antecedent conditions control the soil moisture status (including the ponding of surface water) at the start of a flood-producing event and thus further control the absorption capacity of the soil during the flood. High rainfall in upland areas means that headwater wetlands are frequently saturated. Downstream river-fed wetlands are often relatively dry before a flood and so provide water storage during the flood. These are time-varying conditions that depend on past meteorological circumstances. Flood attenuation also depends on the morphology of the wetland and the ability of the wetland to lose water though both soil drainage and evapotranspiration.

5. Management. Drainage of upland wetlands can increase flood runoff from wetlands. Removal of vegetation reduces friction and increases overland runoff speed in upland wetlands and reduces floodplain attenuation of flood waves. Maintaining low water levels during potential flood periods may enhance soil water storage capacity and reduce floods (though this may conflict with other wetland priorities such as maintenance of biodiversity).

\section{References}

Acreman MC (1985) The effects of afforestation on the flood hydrology of the Upper Ettrick valley. Scottish Forestry 39:89-99. 
Acreman MC, Booker DJ, Riddington,R (2003) Hydrological impacts of floodplain restoration: a case study of the river Cherwell, UK. Hydrology and Earth System Sciences. $7: 75-86$

Acreman MC, Miller F (2007) Hydrological impact assessment of wetlands. In: Ragone S, Hernández-Mora N, de la Hera A, Bergkamp G, McKay, J. (eds.) The global importance of groundwater in the 21st Century: Proceedings of the International Symposium on Groundwater Sustainability. National Groundwater Association Press, Ohio, USA.

Acreman MC, Fisher J, Stratford CJ, Mould DJ, Mountford JO (2007) Hydrological science and wetland restoration: case studies from Europe. Hydrology and Earth System Sciences 11:158-169.

Acreman MC, Harding, RJ, Lloyd C, McNamara NP, Mountford JO, Mould DJ, Purse BV, Heard MS, Stratford CJ, Dury S (2011) Trade-off in ecosystem services of the Somerset Levels and Moors wetlands. Hydrological Sciences Journal 56:8, 1543-1565.

Agarwal A, Chak A (1991) Floods, floodplains and environmental myths. State of India's Environment 3. Centre for Science and Environment, New Delhi.

Archer DR (1989) Flood wave attenuation due to channel and floodplain storage and effects on flood frequency In: KJ Beven, P Carling (eds) Floods: Hydrological, Sedimentological and Geomorphological Implications. John Wiley \& Sons, New York, pp37-46.

Armstrong A, Holden J, Kay P, Francis B, Foulger M, Gledhill S, McDonald AT, Walker A. (2010) The impact of peatland drain-blocking on dissolved organic carbon loss and discolouration of water; results from a national survey. Journal of Hydrology 381:112-120.

Ballard CE, McIntyre N, Wheater HS, Holden J, Wallage ZE (2011) Hydrological modelling of drained blanket peat. Journal of Hydrology 407:81-93.

Baptist MJ, Penning WE, Duel H, Smits AJM, Geerling GW, van der Lee GEM, van Alphen JSL (2004) Assessment of the effects of cyclic floodplain rejuvenation on flood levels and biodiversity along the Rhine River. Rivers Research and Applications 20:285-297.

Bates, P.D, Anderson, MG, Baird, L. , Walling, DE, Simm, D. 1992 Modelling floodplain flows using a two-dimentional finite element model Earth Surface Processes and Landforms, 17, 575-588

Bates PD, Stewart MD, Desitter A, Anderson MG, Renaud J-P (2000) Numerical simulation of floodplain hydrology. Water Resources Research 36:2517-2529

Bay RR (1969) Runoff from small peatland watersheds. Journal of Hydrology 9:90-102. 
Bedinger MS (1981) Hydrology of bottomland hardwood forests of the Mississippi Embayment. In: Clark JR, Benforado J (eds) Wetlands of bottomland hardwood forests, Elsevier, Amsterdam pp161-176.

Benke AC (2001) Importance of flood regime to invertebrate habitat in an unregulated riverfloodplain ecosystem. Journal of the North American Benthological Society 20:225-240.

Betson RP (1964) What is watershed runoff? Journal of Geophysical Research 69:15411552.

Beven K, Germann P (1982) Macropores and Water-Flow in Soils. Water Resources Research 18:1311-1325.

Beven KJ, Kirkby MJ (1979) A physically based variable contributing area model of basin hydrology Hydrological Sciences Bulletin 24:43-69.

Blackwell MSA, Maltby E (2006) Ecoflood guidelines. How to use floodplains for flood risk reduction. EUR 22001 Office for Official Publications of the European Communities, Luxembourg.

Bragg OM, Tallis JH (2001) The sensitivity of peat-covered upland landscapes. Catena 42:345-360.

Brinson MM (1993) A hydro-geomorphic classification for wetlands. Technical Report WRP-DF-4. US Army Engineers Waterways Experimental Station, Vicksburg, Mississippi, USA.

Bromley J, Robinson M, Barker JA (2004) Scale-dependency of hydraulic conductivity: an example from Thorne Moor, a raised mire in South Yorkshire, UK. Hydrological Processes 18:973-985.

Brookes, A. (1985) River channelisation, traditional engineering methods, physical consequences and alternative practices. Progress in Physical Geography 9:44-73.

Bucher EH, Bonetto A, Boyle T, Canevari P, Castro G, Huszar P, Stone T (1993) Hidroviaan initial environmental examination of the Paraguay - Parana waterway. Wetlands for the Americas Publication No. 10, Manomet, MA, USA.

Bullock A, Acreman MC (2003) The role of wetlands in the hydrological cycle. Hydrology and Earth System Sciences 7:358-389.

Burke W (1968) Drainage of blanket peat at Glenamoy. Proceedings of the 2nd International Peat Congress. HMSO, Edinburgh, pp809-817.

Burke W (1975) Aspects of the hydrology of blanket peat in Ireland. Hydrology of marshridden areas, Proceedings of the Minsk Symposium (June, 1972), International Association of Hydrological Sciences, UNESCO/IAHS, Paris, pp171-182. 
Burt TP (1995) The role of wetlands in runoff generation from headwater catchments. In: J. Hughes J, Heathwaite AL (eds) Hydrology and hydrochemistry of British wetlands, Wiley, Chichester, pp21-38

Burt TP (1996) The hydrology of headwater catchments. In: Petts GE, Calow P (eds) River flows and channel forms, Blackwell, Oxford, pp 6-31.

Burt TP (2001) Integrated management of sensitive catchment systems. Catena 42:275-290.

Burt TP, Butcher DP (1985) Topographic controls of soil moisture distributions. European Journal of Soil Science 36:469-486.

CEC (1995) Wise use and conservation of wetlands. Communication from the Commission to the Council and the European Parliament, Commission of the European Communities $\operatorname{COM}(95) 189$ (final).

CEH (1999) Flood estimation handbook. Centre for Ecology and Hydrology, Wallingford.

Chow VT (1959) Open channel hydraulics. McGraw Hill, USA.

CIFOR (2005) Forests and floods Drowning in fiction or thriving on facts? Center for International Forestry Research, Bogor Barat 16680, Indonesia.

Costanza, R. et al., 1997. The value of the world's ecosystem services and natural capital. Nature, 387: 253-260

Cowardine LM, Carter V, Golet FC, LaRoe ET (1979) Classification of wetlands and deep water habitats in the United States. FWS/OBS-79/31. US Fish and Wildlife Service, Washington D.C.

Cowan WL (1956) Estimating hydraulic roughness coefficients. Agricultural Engineering 37:473-475.Constanza R (and 25 others) (1997) The value of the world's ecosystem services and natural capital. Nature 387:253-260.

Darmer KI (1970) A proposed streamflow data program for New York: U.S. Geological Survey open-file report, Albany, New York.

Davies J, Claridge CF (1993) Wetland benefits: the potential for wetlands to support and maintain development. Asian Wetland Bureau Publication No. 87: IWRB Special Publication 27: Wetlands for the America Publication No. 11. Asian Wetland Bureau, Kuala Lumpur, Malaysia.

Davis TJ (1993) Towards the wise use of wetlands. Ramsar Convention Bureau, Gland Switzerland.

Delaney T (1995) Benefits to downstream flood attenuation and water quality as a result of constructed wetlands in agricultural landscapes. Journal of Soil and Water Conservation 50:620-626. 
Devito KJ, Hill AR, Roulet N (1996) Groundwater-surface water interactions in headwater forested wetlands of the Canadian Shield. Journal of Hydrology 181:127-147.

Doyle AF (1987) The Charles River Watershed: a dual approach to floodplain management. Proceedings of the National Wetland Symposium on Wetland Hydrology. Association of State Wetland Managers Inc., Chicago, pp 110-112.

Dugan PJ (1990) Wetland conservation - a review of current issues and required action. IUCN - The World Conservation Union, Gland, Switzerland.

Eggelsmann R, Heathwaite AL, Grosse-Braukmann G, Küster E, Naucke W, Schuch M, Schweickle V (1993) Physical processes and properties of mires. In: Heathwaite AL, Gottlich K (eds) Mires, process, exploration and conservation. John Wiley, Chichester pp 171-262.

Emerton L, Bos E (2004) Value. Counting ecosystems as an economic part of water. IUCN, Gland, Switzerland.

Falconer RH, Cobby D, Smyth P, Astle G, Dent J, Golding B (2009) Pluvial flooding: new approaches in flood warning, mapping and risk management. Journal of Flood Risk Management 2:198-208. DOI: 10.1111/j.1753-318X.2009.01034.X

Fischer B, Turner RK, Morling P (2009) Defining and classifying ecosystem services for decision making. Ecological Economics 68:643-653.

Forest WE, Walker PN (1970) A proposed streamflow data program for Maryland and Delaware, Towson, Maryland, U.S. Geolological Survey Open File Report.

Forster DR, Glaser PH (1986) The raised bogs of south-eastern Labrador, Canada: classification, distribution, vegetation and recent dynamics. Journal of Ecology 74: 47-71.

Gilman K (1994) Hydrology and wetland conservation. John Wiley and Sons, Chichester.

Gilman K (2002) A review of evapotranspiration rates from wetland and wetland catchment plant communities, with particular reference to Cors y Llyn NNR, Powys, Wales. CCW Science Report; 504, Countryside Council for Wales, Bangor.

Glenn MS, Woo M-K (1997) Spring and summer hydrology of a valley-bottom wetland, Ellesmere Island, Northwest Territories, Canada. Wetlands 17:321-329.

Grayson R, Holden J, Rose R (2010) Long-term change in storm hydrographs in response to peatland vegetation change. Journal of Hydrology 389: 336-343.

Haarhoff J, Cassa A (2009) Introduction to Flood Hydrology. Juta Legal and Academic Publishers, Amsterdam 
Harvey, JW., Schaffranek, RW, Noe, GB, Larsen, LG, Nowacki, DJ, \& O’Connor, BL (2009), Hydroecological factors governing surface water flow on a low-gradient floodplain, Water Resour. Res., 45, W03421, doi:10.1029/2008WR007129.

Heathwaite AL (1995) Overview of the hydrology of British wetlands. In: Hughes JMR, Heathwaite AL (eds) Hydrology and Hydrochemistry of British Wetlands. John Wiley, Chichester, pp 11-20.

Hewlett JD , Hibbert AR (1967) Factors affecting the response of small watersheds to precipitation in humid regions. In: Sopper WE, Lull HW (eds) Forest Hydrology. Pergamon Press, Oxford, UK, pp 275-290.

Hillman GR (1998) Floodwave attenuation by a wetland following a beaver dam failure on a second order boreal stream. Wetlands 18:21-34.

Holden J (2005a) Peatland hydrology and carbon cycling: why small-scale process matters. Philosophical Transactions of the Royal Society A 363:2891-2913

Holden J (2005b) Controls of soil pipe density in blanket peat uplands. Journal of Geophysical Research110:F010002

Holden J, Burt TP (2002a) Infiltration, runoff and sediment production in blanket peat catchments: implications of field rainfall simulation experiments. Hydrological Processes $16: 2537-2557$.

Holden J, Burt TP (2002b) Piping and pipeflow in a deep peat catchment. Catena 48:163-199.

Holden J, Burt TP (2003a) Hydrological studies of blanket peat: the significance of the acrotelm-catotelm model. Journal of Ecology 91:86-102.

Holden J, Burt TP (2003b) Runoff production in blanket peat covered catchments. Water Resources Research 39:article number 1191

Holden J, Burt TP (2003c) Hydraulic conductivity in upland blanket peat: measurement and variability: Hydrological Processes 17:1227-1237.

Holden J, Burt TP, Vilas M. (2002) Application of ground penetrating radar to the identification of subsurface piping in blanket peat. Earth Surface Processes and Landforms 27:235-249.

Holden J, Chapman PJ, Labadz JC. (2004) Artificial drainage of peatlands: Hydrological and hydrochemical process and wetland restoration. Progress in Physical Geography 28:95123.

Holden J, Burt TP, Evans MG, Horton M (2006) Impact of land drainage on peatland hydrology. Journal of Environmental Quality 35:1764-1778. 
Holden J, Gascoign M, Bosanko NR (2007) Erosion and natural revegetation associated with surface land drains in upland peatlands. Earth Surface Processes and Landforms 32:15471557.

Holden J, Kirkby MJ, Lane SN, Milledge DJ, Brookes CJ, Holden V, McDonald AT (2008)

Factors affecting overland flow velocity in peatlands. Water Resources Research 44:

W06415.

Holden J, Wallage ZE, Lane SN, McDonald AT (2011) Water table dynamics in drained and restored blanket peat. Journal of Hydrology, 402:103-114.

Holden J, Wearing C, Palmer S, Jackson B, Johnston K, Brown LE (2013) Fire decreases near-surface hydraulic conductivity and macropore flow in blanket peat. Hydrological Processes DOI: 10.1002/hyp.9875

Hooijer A (1996) Floodplain hydrology: an ecologically oriented study of the Shannon Callows, Ireland. Amsterdam University, The Netherlands.

Howe C.P., Claridge G.F., Hughes R. and Zuwendra, 1992. Manual of guidelines for scoping EIA in tropical wetlands. 2nd Edition, Asian Wetland Bureau-Indonesia, Bogor, Indonesia, 261p.

Howie SA, Whitfield PH, Hebda RJ, Munson TG, Dakin RA, Jeglum JK (2009) Water table and vegetation response to ditch blocking: restoration of a raised bog in southwestern British Columbia. Canadian Water Resources Journal 34:381-392.

John, D.M., Leveque, C. and Newton, L.E., 1993. Chapter on West Africa. In: Wetlands of the World I: Inventory, ecology and management, D. F. Whigham, D. Dykyjova and S. Hejny (Eds.) Kluwer, Dordrecht, The Netherlands.

Jones JAA (1997) Pipeflow contributing areas and runoff response. Hydrological Processes $11: 35-41$.

Jones JAA (2010) Soil piping and catchment response. Hydrological Processes 24: 15481566.

Junk WJ, Bayley PB, Sparks RE (1989) The flood pulse concept in river-floodplain systems. Canadian Journal of Fisheries and Aquatic Science 106:110-127.

Kjeldsen T.R. (2009) Modelling the impact of urbanisation on flood runoff volumes. ICE Proc. Water Management, 162, 5, 329-336.

Kjeldsen T.R., Jones D.A. (2009) An exploratory analysis of error components in hydrological regression modelling. Water Resources Research, 45, W02407, 13 pp 
Kloet L (1971) Effects of drainage and runoff and flooding within the Pembina River Basins: North Dakota - Manitoba. Bureau of Sport, Fisheries and Wildlife, Bismarck, North Dakota.

Lane SN, Milledge DG (2013) Impacts of upland open drains upon runoff generation: a numerical assessment of catchment-scale impacts. Hydrological Processes 27:1701-1726.

Lin H (2010) Linking principles of soil formation and flow regimes. Journal of Hydrology 393:3-19.

Lloyd J, Tellam J, Rukin N, Lerner D (1993) Wetland Vulnerability in East Anglia: A Possible Conceptual Framework and Generalized Approach. Journal of Environmental Management, 9, 37, 87-102.

Ludden AP, Frink DL, Johnson DH (1983) Water storage capacity of natural wetland depressions in the Devils Lake basin of North Dakota. Journal of Soil and Water Conservation 38:45-48.

Maltby, E. (1991) Wetland management goals: wise use and conservation. Landscape urban Plan., 20, 9-18.

Maltby E, Hogan DV, McInnes RJ, (1996) Functional analysis of European wetland ecosystems. Report to the European Commission. EC DGXII STEP-CT90-0084.

Maltby, E. and Acreman, M.C. 2011 Ecosystem Services of Wetlands: pathfinder for a new paradigm. Hydrological Sciences Journal. 56, 8 1-19.

Maltby, E, Acreman, MC, Blackwell, M, Everard, M, Morris, J (2013) The challenges and implications of linking wetland science to policy - experience from the UK National Ecosystem Assessment. Ecological Engineering 2414,

Martín-Vide JP, Amarilla M, Zárate FJ (2013) Collapse of the Pilcomayo River. Geomorphology, doi.10.1016/j.geomorph.2012.12.007.

Mazvimavi D (1994) A review of the hydrology of dambos in Zimbabwe In: Matiza T, Crafter S (eds) Wetland ecology and priorities for conservation ion Zimbabwe. IUCN Wetlands Programme, IUCN, Gland, pp 47-53.

McCartney MP (2000) The water budget of a headwater catchment containing a dambo. Physics and Chemistry of the Earth B 25:611-616.

McDonald AT (1973) Some views on the effects of peat drainage. Scottish Forestry 27:315327. 
McDonnell JJ (2003) Where does water go when it rains? Moving beyond the variable source area concept of rainfall-runoff response. Hydrological Processes 17:1869-1875

Millennium Ecosystem Assessment (2005) Ecosystems and human well-being. Island Press, Washington DC, USA.

Mitsch WJ, Gosselink JG (2007) Wetlands. $4^{\text {th }}$ Edition. John Wiley \& Sons, New York.

Moklyak VI, Kubyshkin GP, Karkutsiev GN (1975) The effect of drainage works on streamflow. Hydrology of marsh-ridden areas, Minsk, USSR, 1972. IAHS Studies and Reports in Hydrology, 19: Unesco Press pp 439-446.

Moore RJ (1985) The probability distributed principle and runoff production at point and basin scales Hydrological Sciences Journal 30, 273-297.

Morris J, Hess TM, Gowing DJ, Leeds-Harrison PB, Bannister N, Wade M, Vivash RM (2005) Integrated washland management for flood defence and biodiversity. English Nature Research Reports Number 598, Peterborough.

Mosepele K, Moyle PB, Merron GS, Purkey DR, Mosepele B (2009) Fish, Floods, and Ecosystem Engineers: Aquatic Conservation in the Okavango Delta, Botswana. BioScience 59:53-64.

Natural Environment Research Council (1975) Flood Studies Report. Institute of Hydrology, Wallingford, UK. Five volumes.

Nepf, H.M. 1999 Drag, turbulence and diffusion in flow through emergent vegetation. Water Resources Research, 35.2, 479-489

Nielsen SA, Refsgaard JC, Mathur VK (1991) Conceptual modelling of water loss on floodplains and its application to River Yamuna upstream of Delhi. Nordic Hydrology 22: 265-274.

Novitski RP (1978) Hydrologic characteristics of Wisconsin's wetlands and their influence on floods, streamflow and sediment. In: Wetland functions and values: the state of our understanding. American Water Resources Association, Minneapolis, MN, USA, pp 377 388.

OECD (1996) Guidelines for aid agencies for improved conservation and sustainable use of tropical and sub-tropical wetland. Organisation for Economic Cooperation and Development Development Assistance Committee: Guidelines on Aid and Environment No.9.

Ogawa H, Male JW (1986) Simulating the flood mitigation role of wetlands. Journal of Water Resources Planning and Management 112:114-127. 
Price JS (1992) Blanket bog in Newfoundland: Part 2. Hydrological processes. Journal of Hydrology 135:103-119.

Quinton WL, Roulet NT (1998) Spring and summer hydrology of a subarctic patterned wetland. Arctic and Alpine Research 30: 285-294.

Rameshwaran P (1999) Conveyance prediction for meandering two-stage channel flows. Proceedings of the Institutions of Civil Engineers, Water, Maritime \& Energy 136:153166.

Ramsbottom D (1994) The use of models in river basin flood control. In: Kirby C, White WR (eds) Integrated River Basin Development. Wiley, Chichester, pp 425-435.

Republic of Uganda (1995) National Policy for the conservation and management of wetland resources. Ministry of Natural Resources, Kampala.

Righetti, M., Armanini, A. (2002) Flow resistance in open channel flows with sparsely distributed bushes. Journal of Hydrology, 269, 55-64.

Rodwell JS (1991) British Plant Communities. Volume 2. Mires and Heaths. Cambridge University Press, Cambridge.

Smart RP, Holden J, Dinsmore K, Baird AJ, Billett MF, Chapman PJ, Grayson R. (2013). The dynamics of natural pipe hydrological behaviour in blanket peat. Hydrological Processes. DOI: 10.1002/hyp.9242.

Sparks RE (1995) The need for ecosystem management of large rivers and their floodplains. Bioscience 45:168-182.

Sun X, Shiono K, Rameshwaran P, Chandler JH (2010) Modelling vegetation effects in irregular meandering rivers. Journal of Hydraulic Research 48:775-783.

Sutcliffe JV, Parks YP (1989) Comparative water balances of selected African wetlands. Hydological Sciences Journal 34:49-62.

Swiatek D, Szporak S, Chormański J, Okruszko T (2008) Hydrodynamic model of the lower Biebrza river flow - a tool for assessing the hydrologic vulnerability of a floodplain to management practices. Ecohydrology \& Hydrobiology, 8:24-32.

Thomas, H. \& Nisbet, TR (2007) An assessment of the impact of floodplain woodland on flood flows Water and Environment Journal, 21, 2, 114-126

Thomas H, Nisbet T (2012) Modelling the hydraulic impact of reintroducing large woody debris into watercourses. Journal of Flood Risk Management DOI: 10.1111/j.1753318X.2012.01137.X

Tiner RW (1984) Wetlands of the United States: current status and recent trends. US Fish and Wildlife Sevice, National Wetlands Inventory. Washington D.C. 59 pp. 
Tockner K, Malard F, Ward JV (2000) An extension of the flood pulse concept. Hydrological Processes 14:2861-2883.

Turner N (1757) An essay on draining and improving peat bogs; in which their nature and properties are fully considered. Baldwin and Pew, London.

US Corps of Engineers (1972) An overview of major wetland functions and values. US Fish and Wildlife Service, FWS/OBS-84/18.

Verry ES Boelter DH 1975. The influence of bogs on the distribution of streamflow from small bog upland catchments. Hydrology of marsh-ridden areas, Proc. of the Minsk Symp. (June, 1972), International Association of Hydrological Sciences UNECSO/IAHS, Paris $469-478$

Waddington JM, Lucchese MC, Duval TP (2011) Sphagnum moss moisture retention following the revegetation of degraded peatlands. Ecohydrology 4:359-366, doi: 10.1002/eco.130.

Wallage ZE, Holden J, McDonald AT (2006) Drain blocking is an effective treatment for reducing dissolved organic carbon loss and water colour in peatlands. The Science of the Total Environment 367:811-821.

Wakelin MJ, Walker TG, Wilson D (1987) Lincoln flood alleviation scheme. Proceedings of the Institution of Civil Engineers 82:755-776.

Ward R (1978) Floods. A geographical perspective. MacMillan Press, London.

Wilson L, Wilson JM, Johnstone I, Holden J, Armstrong A, Morris, M (2011a) The impact of drain blocking on an upland blanket bog during storm and drought events, and the importance of sampling-scale. Journal of Hydrology 404:198-208.

Wilson L, Wilson JM, Holden J, Johnstone I, Armstrong A, Morris M (2011b) Ditch blocking, water chemistry and organic carbon flux: evidence that blanket bog restoration reduces erosion and fluvial carbon loss. Science of the Total Environment 409:2010-2018.

World Conservation Monitoring Centre. 1992. Global Biodiversity: Status of the Earth's Living Resources. Chapman \& Hall, London.

Woo M-K, Young K (1998) Characteristics of patchy wetlands in a polar desert environment, Arctic Canada. Proceedings, $7^{\text {th }}$ International Conference on Permafrost, 23-27 June, Yellowknife, pp 1141-1146.

Zedler JB, Kercher S (2005) Wetland resources: status, trends, ecosystem services, and restorability. Annual Review of Environment and Resources 30: 39-74.

Zwarts L, Cisse N, Diallo N (2005) Hydrology of the Upper Niger. In: Zwarts L et al (eds) The Niger, A Lifeline. Effective Water Management in the Upper Niger Basin. Institiute 
for Inland Water Management and Waste Water Treatment, Lelystad, The Netherlands, pp $15-41$. 


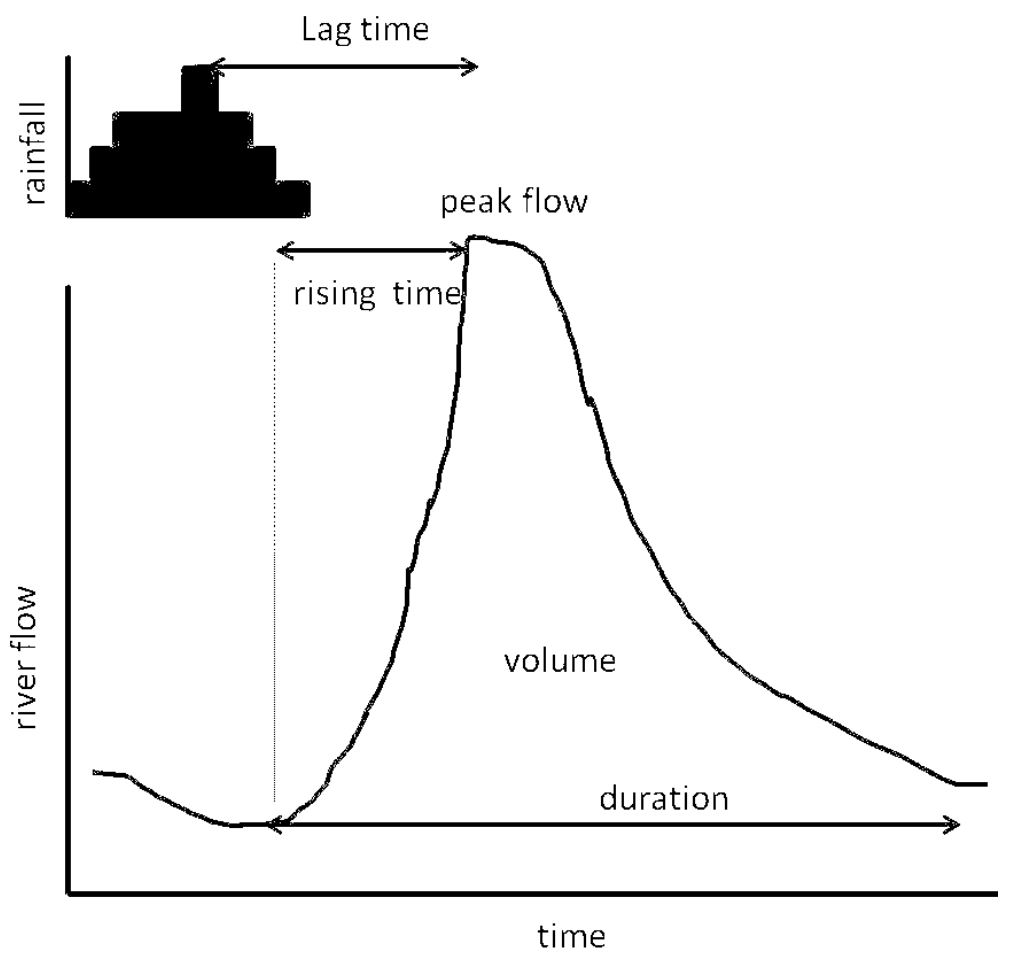

Figure 1. Hypothetical river flood hydrograph 

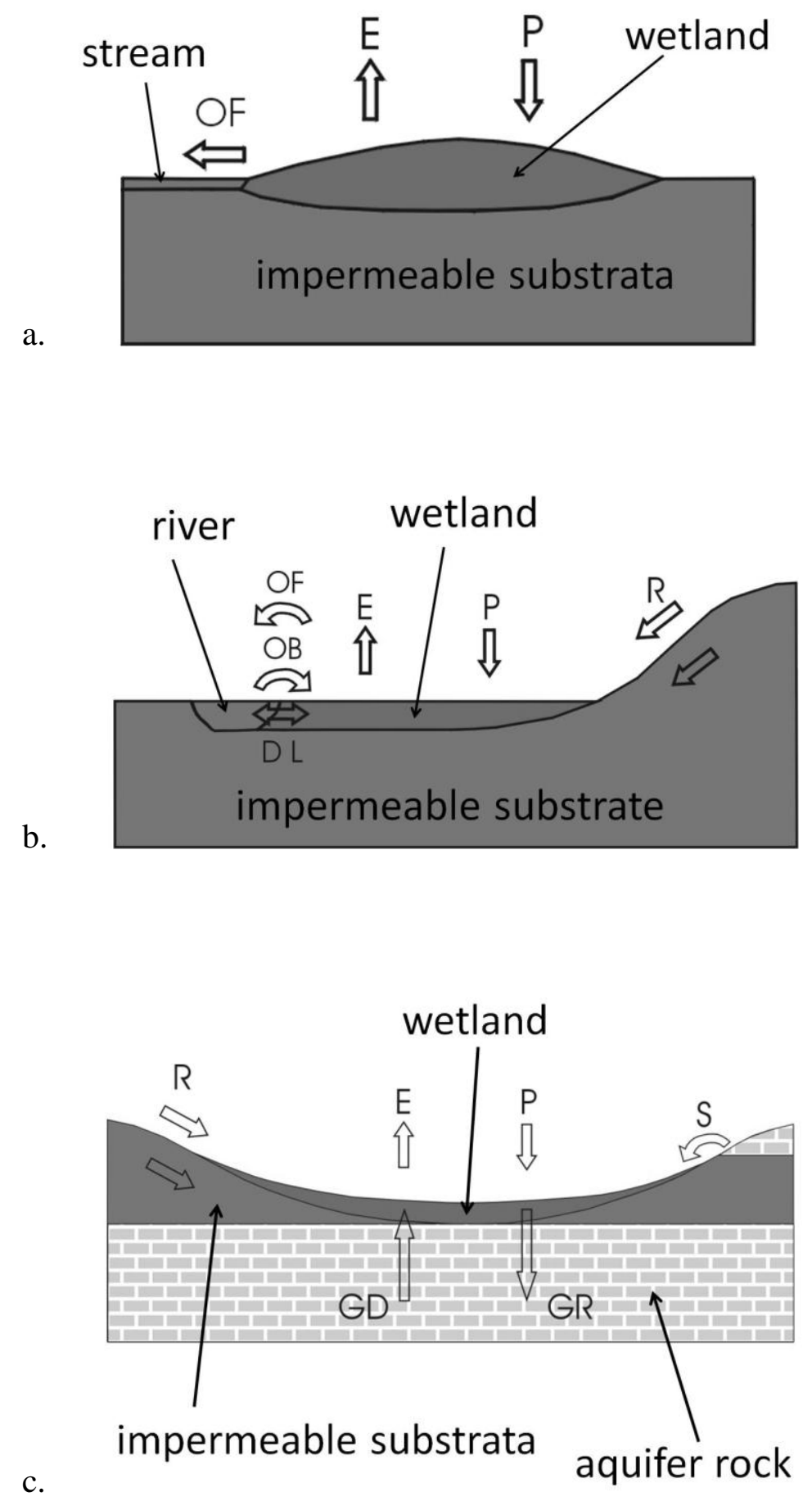

Figure 2. Simple classification of wetlands according to water supply mechanism (a. precipitation-fed, b. river-fed and c. groundwater-fed). $P=$ precipitation, $E=$ =vaporation, R=runoff, GD=groundwater discharge, GR=groundwater recharge, $O F=$ outflow, $\mathrm{OB}=$ overbank flooding, $\mathrm{D}=$ drainage, $\mathrm{L}=$ lateral inflow $\mathrm{S}=$ spring flow (after Acreman and Miller 2007). 


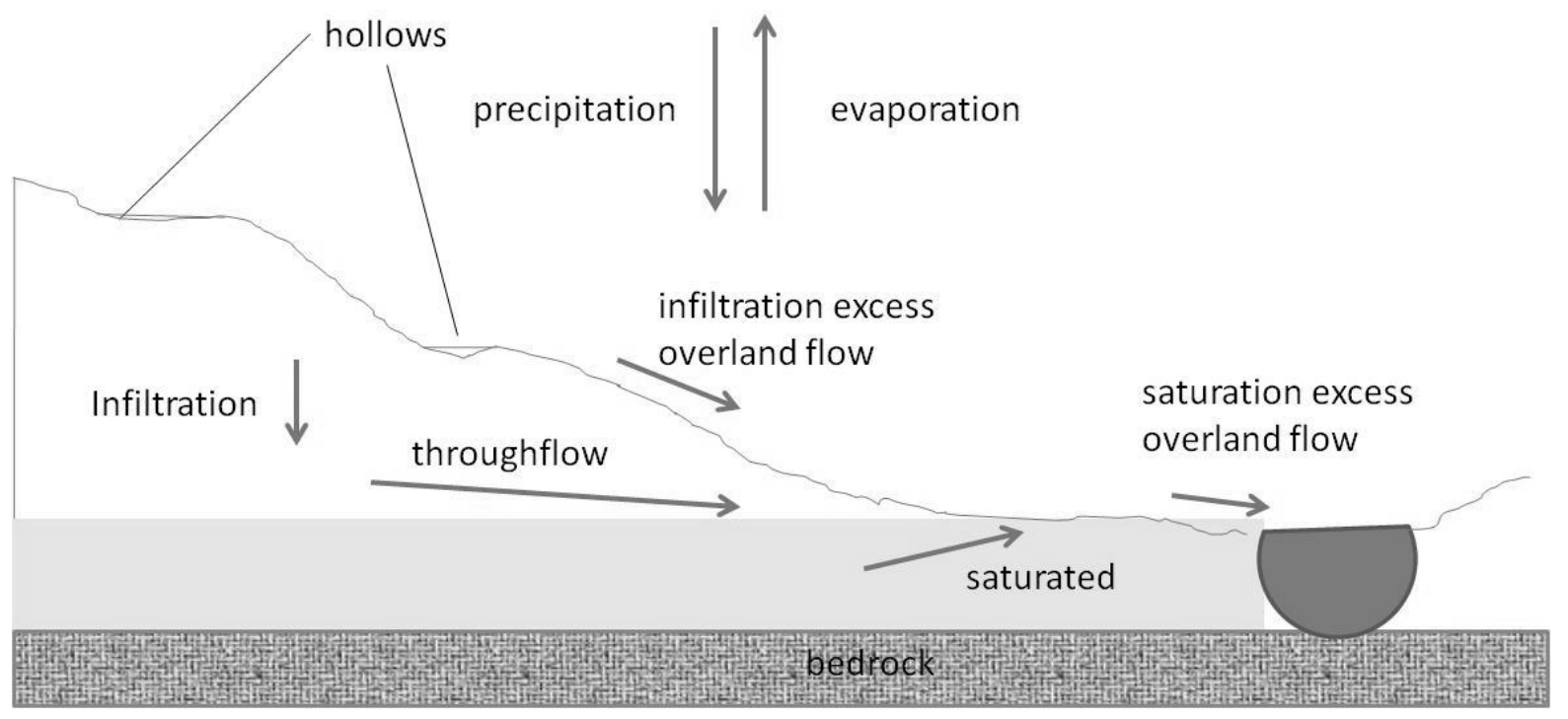

Figure 3. Schematic diagram of runoff pathways 
a)

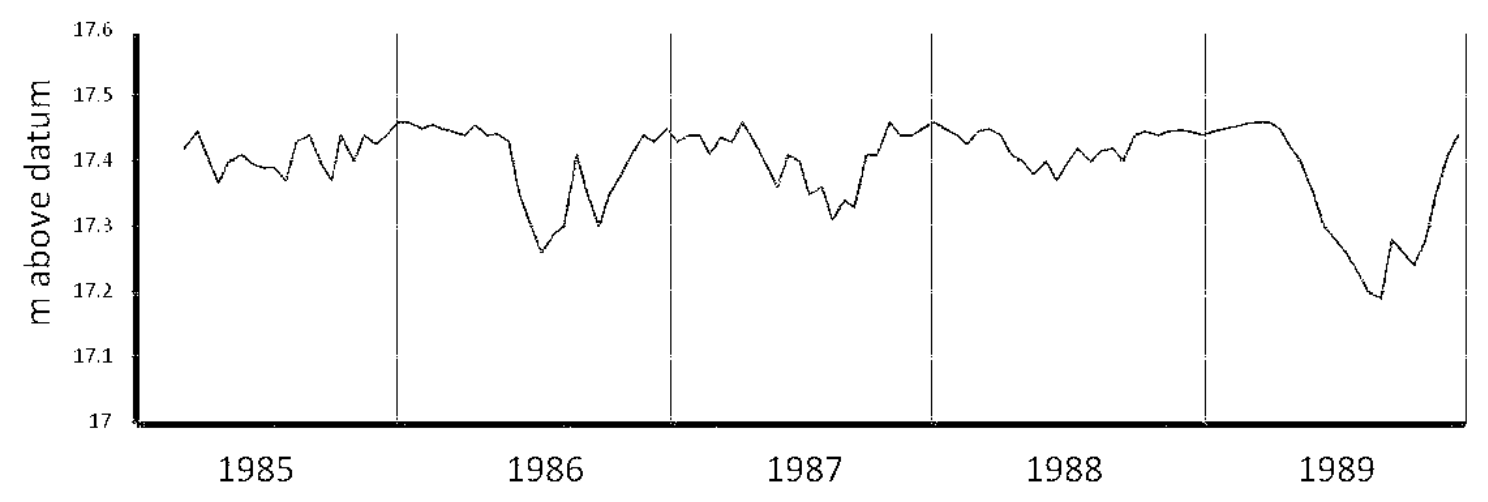

b)

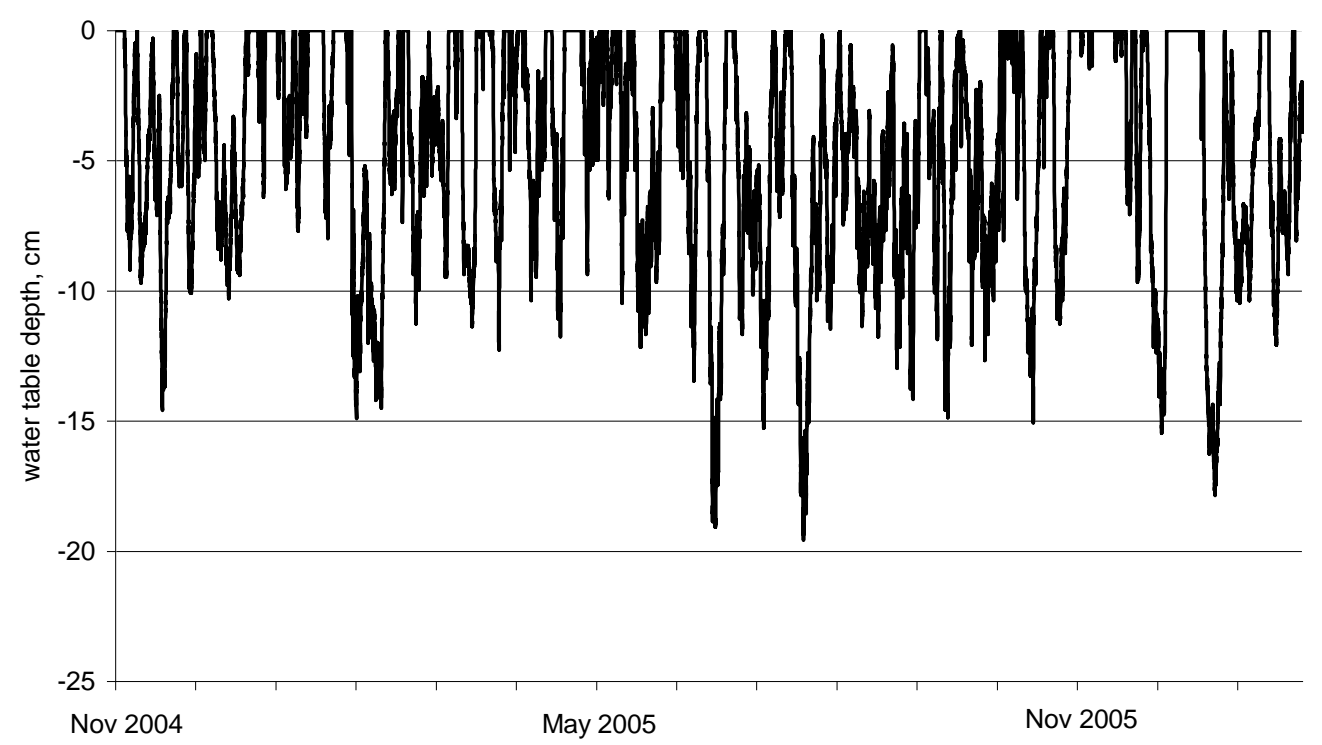

Figure 4. Example upland wetland water tables a) Cors-y-Llyn, Wales (after Gilman 1994) showing seasonal response and b) blanket bog in Upper Wharfedale showing fast response to individual rainfall events - the water table was at the surface (i.e. saturation except for trapped gas bubbles) for $27 \%$ of the time at the measurement point. 


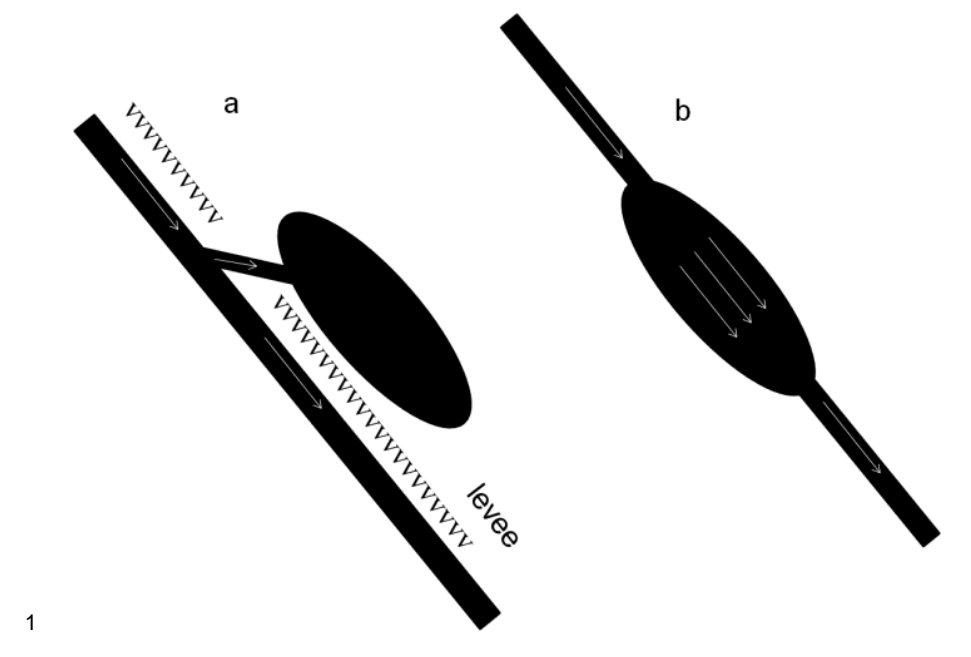

Figure 5 Schematic of river and floodplain. In (a) water flows into dead storage on the floodplain behind a levee. In (b) water flow onto and along the floodplain parallel with the river flow 


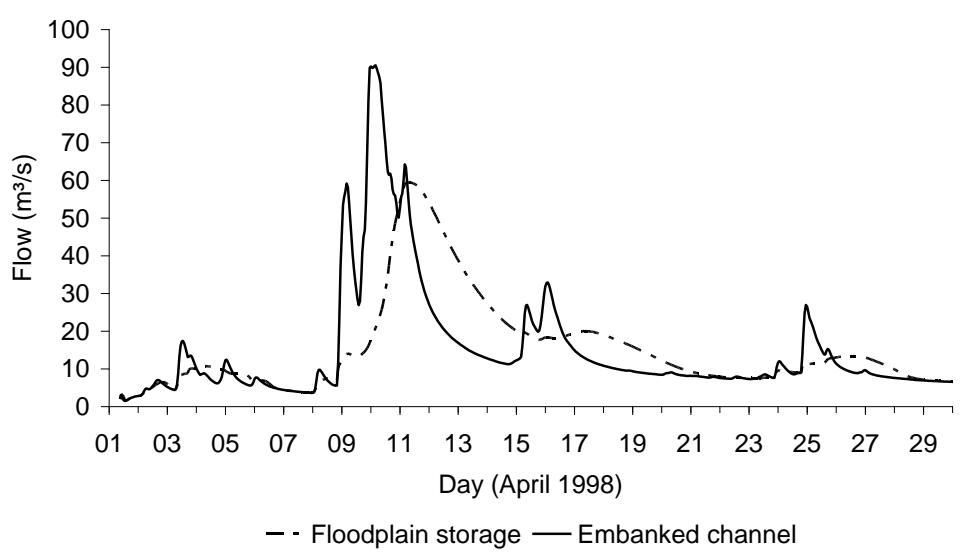

Figure 6. Observed flows on the River Cherwell (dashed line) compared with modelled flows (solid line) from removing floodplain storage by embanking the river (Acreman et al., 2003). 


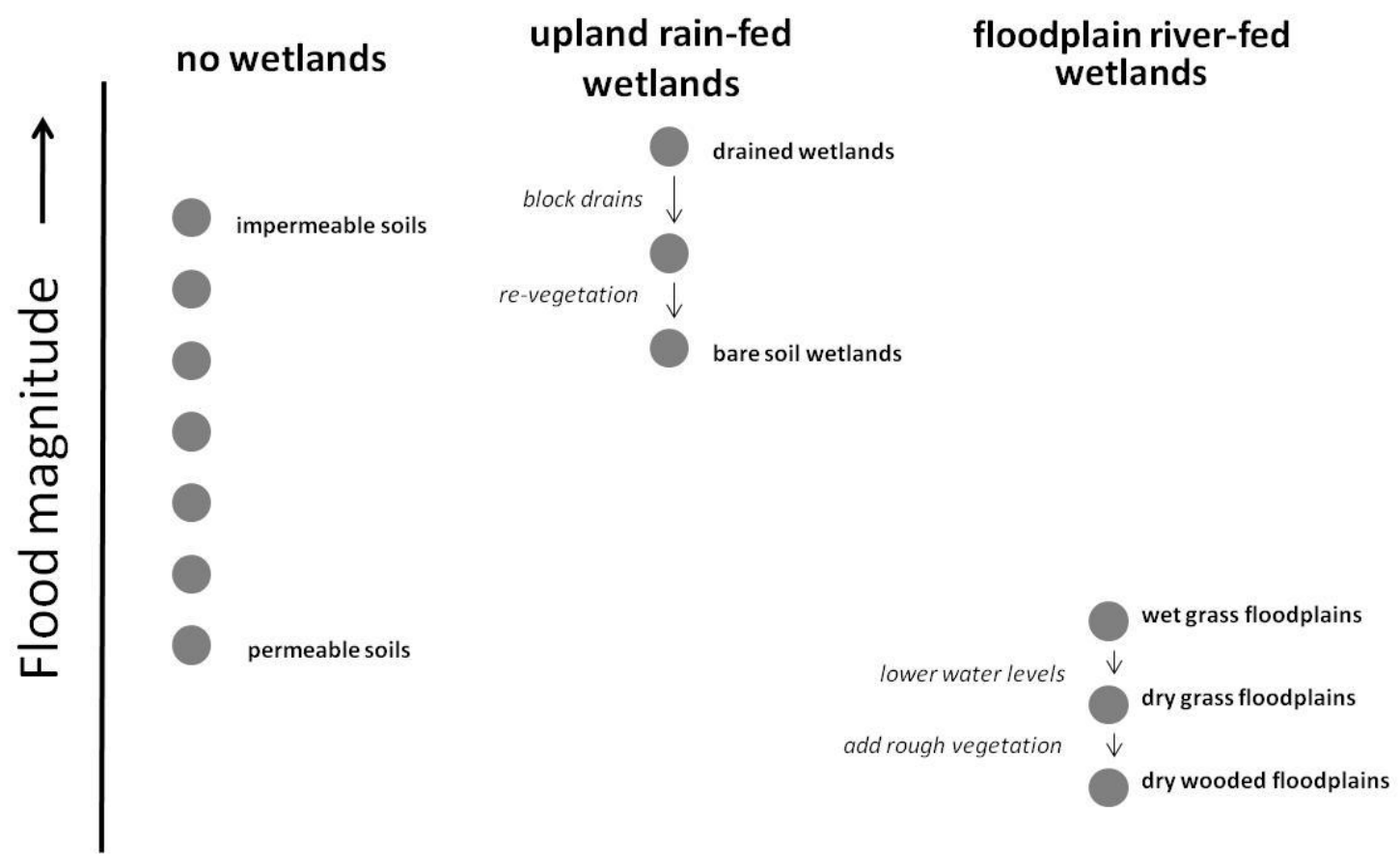

Figure 7. Relative impact of wetlands and management regimes on floods Circles on the left of the figure show the natural variation in flood magnitude between river basins resulting from differences in soil type (other basin characteristics being equal) with no wetlands. Circles on the right show the relative magnitude of floods in river basins with different wetlands under different management regimes. 